Elsevier required licence: (C) <2019>. This manuscript version is made available under the CC-BY-NCND 4.0 license http://creativecommons.org/licenses/by-nc-nd/4.0/

The definitive publisher version is available online at

[https://www.sciencedirect.com/science/article/pii/S0959652619324679?via\%3Dihub] 


\section{Barriers to green supply chain management: An emerging economy context}

\section{Abstract}

4 Green supply chain management is attracting increasing attention as a way to decrease the 5 adverse environmental effects of industries worldwide. However, considering the context of an emerging economy like Bangladesh, green supply chain management is still in its inception and

7 has not been widely embraced in the textile industry, and therefore barriers hindering its adoption 8 in emerging economy context demand a comprehensive investigation. This research reviews the viewpoints and hurdles in adopting green supply chain management practices in the context of the Bangladeshi textile industry. A questionnaire survey of Bangladeshi textile practitioners of

12 to identify the barriers, and a hierarchical cluster analysis technique was used in the detailed 13 analysis of this data. Opinions were sought from experts on the significance of the resulting 14 clusters, considering the relative importance of the barriers. Fifteen barriers to the adoption of 15 green supply chain management were identified in the review of the literature, with these barriers 16 then analyzed by using the data collected from Bangladeshi textile industry practitioners. The 17 research indicates that the most important barrier is that there is low demand from customers and 18 financial constraint resulting from short term little financial benefit to businesses, with lack of 19 government regulations also a commonly faced barrier in adopting green supply chain initiatives.

20 This study will provide valuables insights to practitioners and relevant policy makers about the 21 barriers prevailing in the emerging economies towards the adoption of green supply chain 22 management practices, which, in turn, can guide to undertake appropriate steps for alleviating 23 those barriers.

24 Keywords: Green supply chain management process (GSCMP); Hierarchical cluster analysis; 25 Textile industry; Emerging economy.

\section{Introduction}

27 The global textile industry is a complex industry consisting of agricultural, chemical industry, 28 cotton manufacturing, synthetic fiber, clothing, retail, logistics and waste disposal units (Beton et 29 al., 2014). Processes of the textile industry have long been criticized for being the major 
contributors of harmful environmental activities including high volume wastage of non-renewable

31 resources, global warming, and the heavy use of pesticides and harsh toxic chemical materials

32 (Alay et al., 2016). These processes and use of several chemicals not only increase environmental

33 concerns, but also create greenhouse gas emission, cause depletion of water and resources,

34 acidification and several health problems (Alay et al., 2016); (Roos, 2015a). As a result, the textile

35 industry feels the pressure to implement environmental-friendly supply chain processes due to

36 increased public awareness and government regulations (Diabat et al., 2014). In such environment-

37 friendly processes, manufacturers generally include those components, which impose least

38 negative impact on human health and environment during production, consumption, conservation,

39 and disposal of the textile products. Green supply chain management process (GSCMP), which

40 considers the safety of the environment at every phase of the process, is considered to be an

41 effective method of decreasing the adverse environmental impacts of the production of textile

42 products (Roos, 2015b). Moreover, adopting GSCMP can help textile companies save huge

43 operational energy, cut costs, improve efficiency and reduce the amount of toxic waste generation

44 (Oliveira et al., 2018). Furthermore, to assert the better business opportunities and gain a strong 45 market position by creating a sensation of good brand image amongst the consumers, adoption of

46 GSCMP is a must (Ageron et al., 2012).

Although there are many advantages related to green supply chain adoption, the textile industry of emerging economies has not yet embraced it widely, rather still in a pre-mature state 49 of adopting GSCMP (Nayak et al., 2019). For example, among the textile companies in Asia, where a large volumes of textile products are produced, very few are concerned about recyclable and renewable materials (Islam et al., 2018). Given that emerging economies play a substantial 52 role in textile production, it has become imperative to understand which factors impede the 53 adoption of GSCMP in such countries. However, there is a lack of studies on the barriers of 54 GSCMP adoption in the textile industry of emerging economies (Majumdar and Sinha, 2019). On 55 the other hand, there are many studies that discusses the barriers of GSCMP either in the context 56 of other industries, such as agriculture or automobile, or in the context of developed economies 57 (Blok et al., 2015); (Kaur et al., 2018); (Lorek and Spangenberg, 2014); (Oliveira et al., 2018). 58 Due to the unique characteristics of the textile industry of the emerging economies, the findings of 59 the other set-up may not be applicable in this context (Routroy and Shankar, 2014), and need a 60 context-focused study to explore the barriers of GSCMP. 
Therefore, this study aims at exploring and analyzing the barriers of GSCMP in the context

62 of an emerging economy. The study uses Bangladesh, a country of South Asia, as an example of 63 emerging economy to analyze the barriers of GSCMP to supplement the knowledge gap in this

64 regard. The study uses Bangladesh as this country is among the leading producers and exporters 65 of textile products and as a result is more critically subjected to the adverse environmental effects 66 of textile production (Angel et al., 2015). Moreover, similar to other emerging countries, textile 67 practitioners in Bangladesh have low environmental consciousness; although some have 68 incorporated initiatives in their business strategies, the majority are still ignorant of the environmental effects of their industrial activities (Majumdar and Sinha, 2019). Moreover, in Bangladesh, there is a negligible amount of research that analyzes barriers to the adoption of GSCMP in the textile sector (Islam et al., 2018). Bangladesh has achieved noteworthy economic expansion in the last few decades and textile industry is one of the major contributors to this economic growth. Considering the harmful effects of the industrial processes of textiles on the natural environment, it has become acute for the Bangladesh textile industry to adopt immediate measures towards greening their supply chain and mitigating the barriers associated with it (Jayaram and Avittathur, 2015). However, the mitigation is not possible until the barriers are clearly identified and analyzed to understand which barrier is more critical than others. Once these are done, the practitioners and the policy makers of the industry would be able to undertake proper strategies to alleviate these hurdles.

A detail analysis is done to identify the most common and critical barriers using the hierarchical clustering analysis. This technique is used to identify the barriers in considering their association and thus it removes the weakness of evaluating the barriers using the traditional quantitative approaches. Where traditional methods evaluate the barriers only considering their relative importance, hierarchical cluster analysis technique evaluates the barriers from two perspectives: first one is that it measures the influence of each barriers on GSCMP by considering the relative importance and the second one is it considers the variations in opinions among the respondents regarding the importance of the barriers. Further analysis is done to find out the possible reasons of opinion divergence among the respondents about the same barrier, which barriers are critical for certain practitioners (opinions divergence barriers) and which are the commonly faced critical barriers for all the practitioners (the consensus barriers). 
In doing so, the study contributes substantially to the scarce literature on the barriers of

92 adopting GSCMP in the textile industry (Majumdar and Sinha, 2019). Specifically, the study adds

93 to the literature on emerging economies by identifying and providing the barriers of GSCMP. This

94 will help to differentiate the ways textile industry of emerging economies face barriers to

95 implement GSCMP when compared to textile industry of developed countries and other industries

96 of the emerging countries. Moreover, the study analyzes the barriers to identify the most common

97 and critical barriers in this regard. Previous studies in the context of other industries or

98 environmental set-up totally different than emerging economies already provided dissimilar set of

99 critical barriers of adopting GSCMP. For example, while Gold et al. (2013) mention two most

100 critical barriers towards the adoption of GSCMP are disintegrated supply chain and illiteracy of

101 business practitioners about the advantages of GSCMP adoption, Blok et al. (2015) report that the

102 lack of appropriate methods, tools and techniques to address environmental effects are the most

103 crucial barriers of the implementation of GSCMP. These divergent findings suggest the need of an

104 in-depth analysis in the context of the textile industry of the emerging economies to ensure that

105 the findings are truly reflect the industry and context. Furthermore, by employing hierarchical

106 cluster analysis this study differentiated between opinion divergence barriers and opinion

107 consensus barriers, which is a unique contribution of this study.

108 The remainder of this article is structured into six sections: Section 2 contains the related

109 literature review; Section 3 elucidates the methodology of our research; Section 4 presents the data

110 survey results; Section 5 discusses the data analysis; Section 6 presents the discussion, implications

111 and contributions of the study findings; and the conclusion, along with future research directions,

112 of the study is given in Section 7.

\section{Literature Review}

\section{$114 \quad 2.1$ Conceptualization of Green Supply Chain Management}

115 Green supply chain is a concept that is gaining increasing popularity day by day because of its 116 commitment to sustainability for the companies (Oliveira et al., 2018). Green supply chain is seen 117 not only as an enabler of environmental enhancement like reduction in usage of chemicals and 118 toxic materials, energy consumption, waste generation, air pollution etc. but also it boosts 119 economic performance and competitive advantage (Rao and Holt, 2005). Green supply chain 120 management demands integration and co-ordination of the business segments and strategy 
121 alignment which includes inbound logistics, internal supply chain and production process, 122 outbound logistics, reverse logistics, customer requirements, responsiveness, quality and 123 efficiency.

124 Introducing green supply chain practice in different segments of the business process results in 125 a coordinated green supply chain. Green supply chain yields better environmental and economic 126 performance in the individual supply chain partners which results in overall improvement of the 127 business organization (Green et al., 2012).

\subsection{Emerging economy}

Emerging economy illustrates a nation's growth of economy due to rapid growth of industrialization and increased business with other countries. Developing countries with emerging

131 market economy have become a hub for international business. Due to low manufacturing cost 132 many giant companies have shifted their manufacturing plants in such countries. As a result, those 133 countries enjoy cross border trade and redefined international regulations. Such nations are 134 experiencing an influential role in world economy. However, unlike developed countries where 135 the market is mature, many emerging market economies are volatile and are subject to uncertainty 136 (Chowdhury et al., 2019). Moreover, emerging economies have lack of environmental awareness, 137 and, hence, are lagging to adopt green practices in the supply chain. Therefore, emerging markets 138 poses a higher threat to the environment (Mani et al., 2018), however, adoption of GSCMP can rectify the threat (Moktadir et al., 2018); (Pandit et al., 2017).

140 Bangladesh, as an emerging economy, is not an exception, rather poses higher threat to the 141 environment due to lack of sustainable practices. In the country, textile industry plays the key role 142 in the economic advancement as it contributes significantly to export earnings and creates 143 substantial employment including women employment (Cheng et al., 2018). Moreover, because 144 of cheap labor, quality product and availability of modernized transportation system, many famous 145 fashion retailers have concentrated their manufacturing operations in Bangladesh (Huq et al., 146 2016). Although currently the industry has the lack of environment concerns, it has huge scope for 147 implementing sustainability practices, including minimization of waste generation and energy 148 consumption, resource conservation, reuse and recycling, and therefore the potential to adopt 149 sustainable business practices (Islam et al., 2018). In order to utilize this potentiality, Bangladeshi 150 textile industry needs to properly identify and analyze the barriers of GSCMP. 


\subsection{Barriers to green supply chain management in emerging economy}

152 Green supply chain management has not yet been popularized in emerging economy like 153 Bangladesh (Ali et al., 2017). The textile industry is an important labor-based, export-oriented 154 sector in Bangladesh (Ahmad et al., 2018). Many foreign investors are attracted to investments 155 and projects in Bangladesh due to cheap labor and low cost of products. For example, Berg et al. 156 (2011) reports that 80 per cent of European and American brands are planning to move their 157 production plants from Chain to Bangladesh due to low cost of productions. The contribution of 158 this industry to the Bangladesh economy is also increasing day by day (Bangladesh Economic 159 Review, 2018). However, this growth may not sustain in the long run if the manufacturers of the 160 industry do not adopt green practices. This is because buyers of the developed countries are 161 increasingly becoming aware about the environment and providing stringent environment 162 requirements before making contract with the suppliers of emerging countries (Biju et al., 2015).

163 Some of these buyers are even ready to pay more and shift their production plants from low-cost 164 countries to comparatively higher cost countries to ensure that they maintain sustainable practices in sourcing (Luthra et al., 2014). The current scenario is not pleasing for the Bangladeshi textile manufacturers as they lack the sustainable practices in their supply chain (Rakib et al., 2017). This suggests an study to find out which factors hinders the adoption of GSCMP in the textile industry of Bangladesh.

Through a comprehensive literature review, the following sub-sections identify the common barriers encountered in GSCMP adoption. The barriers were categorized from the perspectives of

171 government rules and regulations, characterizations of green materials, business organization, 172 market demand, and lack of standards and the flow of raw materials. We then listed the barriers 173 specifically encountered in the Bangladeshi textile industry.

\section{$174 \quad$ 2.3.1 Government policy}

175 The success of encouraging green initiatives in industrial sectors profoundly depends on 176 governmental policies (Lorek and Fuchs, 2013). Often policymakers find it difficult to address the 177 pattern of unsustainable consumption and how to encourage the development of sustainable 178 consumption (Tseng et al., 2013). Cooper (2005) stresses the importance of Life Cycle Analysis 179 (LCA), which is an assessment technique to determine the impact of associative stages of a 180 product's life from the extraction of raw material to a disposal, to understand whether to emphasize 
waste reduction or to lower energy consumption. Blok et al. (2015) suggest that governments

182 should emphasize on incentive programs rather than rules and regulations to encourage the

183 industries to adopt green supply chain initiatives. O'Brien and Li (1999), recommend that

184 government should negotiate with industry professionals to achieve rational goals regarding

185 GSCMP.

186

187

188

189

190

191

192

193

194

195

196

197

198

199

200

\subsubsection{Attributes of green and eco-friendly materials}

The increased cost incurred by producing green products is identified to be the most critical barrier towards GSCMP implementation (Luthra et al., 2011). In the textile industry, procurement of green and eco-friendly materials incurs an additional cost, which will increase overall investment. When an organization adopts GSCMP in early stages it incurs an extra cost because of lack of experience available in using new materials and undertaking new technology, design and construction processes (Ageron et al., 2012). Therefore, the idea for the adoption of green materials will fall into risks of ruining their financial performance discourages practitioners to undertake GSCMP initiatives. Besides the financial risk, green supply chain initiatives may inherit operational risks, such as incompatibility with other materials, higher requirements for materials handling, changing infrastructure, and dealing with the incompetent workforce (Grimm et al., 2014). Moreover, there may occur many technical problems in using the green products available in the current market (Govindan et al., 2014). Generally, small and medium-sized enterprises (SMEs) show comparatively more reluctance to adopt GSCMP since they lack of financial resources and strategic view in adopting GSCMP (Lee, 2008).

\subsubsection{Business organization}

Among all the green schemes, upgrading organizational environmental performance through green supply chain initiatives is of utmost importance for industry professionals (Luthra et al., 2011). However, it appears that practitioners are not yet ready to implement GSCMP organizationwide. Bunse et al. (2011) find that extensive and easy-to-use tools for measuring the environmental performance of green materials are not available to industry professionals, which is a major impediment to GSCMP initiatives. The inexperience of industry practitioners in adopting GSCMP can magnify the initial cost of green supply chain schemes. Eventually, professionals who are not involved in green supply chain tend to overestimate the additional cost of GSCMP initiatives. This overestimation leads professionals to use conventional supply chain processes, as these seem to be 
212 chain initiatives and organizational environmental policies taken by the managerial staff are the 213 main enablers of GSCMP adoption (Blok et al., 2015).

214 In Bangladesh, entrepreneurs are notably found to be ignorant of environmental missions and 215 policies and only a few of them are found to adopt some green initiatives in their supply chain. 216 This situation indicates that the top management is not supportive towards GSCMP adoption 217 (Lorek and Fuchs, 2013). Lack of environmental missions and strategies is therefore believed to 218 be a major barrier to the adoption GSCMP. Given that green supply chain initiatives cannot be 219 implemented effectively without coordination from all departments (Zsidisin and Siferd, 2001), 220 the top management should carefully assign environmental responsibilities among individual 221 departments and achieve the organization's environmental goals through coordination and support 222 from all departments. The misleading conception of environmental responsibilities among industry 223 professionals will adversely affect GSCMP adoption.

224 In addition to this, lack of consciousness about environmental factors among managerial staff 225 hinders GSCMP initiatives (Al Zaabi et al., 2013). The professionals who are unconscious and 226 ignorant of environmental issues hampers the adoption of sustainable practices and the promotion 227 of green industries. Sometimes the unsatisfactory experience of using green materials discourages 228 practitioners from adopting GSCMP. Grimm et al. (2014) find that, due to the bad performance of 229 green materials in both cost advantage and compatibility, some industries are not interested in 230 green supply chain. Deficiency of green and eco-friendly supplies could also significantly 231 discourage the industries from GSCM adoption (Lorek and Spangenberg, 2014).

\section{$232 \quad$ 2.3.4 Market condition}

233 The drivers a supply chain to be green are mainly operational cost savings, efficiency 234 improvement, creating brand image etc. However, there is a common belief among textile 235 professionals that the external incentive to undertake environmental initiatives only comes from 236 market. Also, consumers lack awareness regarding green products (Lorek and Spangenberg, 2014) 237 (Lorek and Spangenberg, 2014). This makes market demand of green products uncertain. This 238 uncertainty inhibits practitioners from adopting GSCMP initiatives (Luthra et al., 2014). Although 239 buyers from developed countries are increasingly demanding green textile products, consumers in 240 emerging economies, such as Bangladesh, neglect the detrimental effects of the products on 
241 environment rather they focus on price and quality of the garment products. In fact, a recent study

242 (Kaur et al., 2018) suggests that even the customers of developed countries do not have sufficient

243 levels of awareness regarding the green supply chain or green products. Moreover, prior studies

244 suggest that while the cheapest price is the main criteria in low-cost country sourcing, the

245 competence of adopting green supply chain by the suppliers is often ignored in the process of

246 supplier selection (Kusaba et al., 2011). As a result, manufacturer in the developed countries like

247 Bangladesh focus on achieving the cheapest price of the products as their main competitive

248 advantage (Cheng et al., 2018). In other words, this lack of pressures from the customers hinders

249 the motivation of the manufacturers in the emerging markets to adopt GSCMP.

$250 \quad$ 2.3.5 Standards and materials supply

251 The absence of proper certification systems makes it hard for practitioners to compare 252 alternative green materials and processes. Therefore, practitioners are bound to apply traditional 253 materials and processes (Akadiri, 2015). In Bangladesh, there are not sufficient standards available 254 for GSCMP, although few non-authoritative standards for specific green categories are available 255 (Islam et al., 2018). Consequently, practitioners are not attracted to adopt these non-authoritative 256 standards. Findings indicated that there are not enough authoritative certification standards for 257 textile industries in Bangladesh, which can inhibit companies from adopting GSCMP.

258 Insufficient green materials in the local market is also a major barrier for adopting green supply 259 chain in many industrial sectors in Bangladesh. Moreover, suppliers are reluctant to change 260 towards GSCMP due to own interest and traditional mindset (Mudgal et al., 2010). This type of 261 attitude inhibits the whole network from adopting GSCMP initiatives. In this case, management 262 prefers taking a low risk path i.e. purchasing raw material from the conventional sources. Often 263 producers fail to take the responsibility of products, especially post-sale liability of their products 264 (Lorek and Spangenberg, 2014).

265 The literature review identified the barriers preventing GSCMP implementation in different 266 industrial sectors. However, different organizations may face different hurdles while undertaking 267 GSCMP initiatives in their supply chains. As a result, a barrier in one industry may not be such in 268 another, or the impact of a specific barrier may differ from industry to industry (Diabat et al., 269 2014). Going through the current literatures and gathering views from textile practitioners through 270 both emailed and on-site questionnaire surveys, fifteen significant barriers to the adoption of 
271 GSCMP initiatives in the Bangladeshi textile industry were identified and are presented in Table 2721.

Table 1: Barriers to GSCMP in textile industry of Bangladesh

\begin{tabular}{|c|c|c|}
\hline Code & Important barriers & References \\
\hline B1 & $\begin{array}{l}\text { Lack of attention to develop theories and } \\
\text { increase research work in green business } \\
\text { practices }\end{array}$ & $\begin{array}{l}\text { (Govindan et al. 2014); (Ahamed, 2013); } \\
\text { (Asgari and Hoque, 2013) } \\
\text { (Ahmed et al., 2014); (Anisul Huq et al., } \\
\text { 2014); (Barua and Ansary, 2017); (Wadud } \\
\text { and Huda, 2017); (Khan and Qianli, 2017) }\end{array}$ \\
\hline B2 & $\begin{array}{l}\text { Lack of collaboration among supply chain } \\
\text { partners due to complex supply chain }\end{array}$ & $\begin{array}{l}\text { (Bhuiyan and Haq, 2008); (Sarkis 2003); } \\
\text { (Liu et al. 2012); (Gold et al. 2013); } \\
\text { (Haque and Azmat, 2015); (Khan and } \\
\text { Qianli, 2017); (Khan et al., 2016); (Fontana } \\
\text { and Egels-Zandén, 2018) }\end{array}$ \\
\hline B3 & Less incentives from the government & $\begin{array}{l}\text { (Blok et al. 2015); (Parent et al. 2013); } \\
\text { (Khosla, 2009); (Wadud and Huda, 2017); } \\
\text { (Khan and Qianli, 2017) }\end{array}$ \\
\hline B4 & $\begin{array}{l}\text { Lack of interest and effective efforts of } \\
\text { stakeholders }\end{array}$ & $\begin{array}{l}\text { (Jones et al. 2011); (Liu et al. 2012); } \\
\text { (Almeida et al. 2013); (Ahamed, 2013); } \\
\text { (Asgari and Hoque, 2013); (Wadud and } \\
\text { Huda, 2017); }\end{array}$ \\
\hline B5 & Financial constraints & $\begin{array}{l}\text { (Ageron et al. 2012); (Grimm et al. 2014); } \\
\text { (Govindan et al. 2014); (Luthra et al. } \\
\text { 2011); (Araujo Galvão et al., 2018) }\end{array}$ \\
\hline B6 & Unskilled workforce & $\begin{array}{l}\text { (Luthra et al. 2011); (Berg, 2011); } \\
\text { (Longoni et al. 2014); (Urban and Naidoo, } \\
\text { 2012) }\end{array}$ \\
\hline B7 & $\begin{array}{l}\text { Organizational culture resistance to } \\
\text { change }\end{array}$ & $\begin{array}{l}\text { (Carter and Rogers 2008); (Kamalakanta } \\
\text { Muduli et al. 2013); (Zhu and Geng, } \\
\text { 2013); (Abubakar, 2018); (Gaur and Mani, } \\
\text { 2018); (Govindan and Hasanagic, 2018) }\end{array}$ \\
\hline B8 & Lack of top management commitment & $\begin{array}{l}\text { (Govindan et al. 2014); (Lorek and } \\
\text { Spangenberg 2014); (Dubey et al. 2015); } \\
\text { (Zhu and Geng 2013); (Khan and Qianli, }\end{array}$ \\
\hline
\end{tabular}




\begin{tabular}{|l|l|l|}
\hline & \multicolumn{1}{|c|}{} & $\begin{array}{l}\text { 2017); (Khan et al., 2016); (Govindan and } \\
\text { Hasanagic, 2018) }\end{array}$ \\
\hline B9 & $\begin{array}{l}\text { Lack of third parties to recollect used } \\
\text { products }\end{array}$ & $\begin{array}{l}\text { (Govindan et al. 2014); (Smol et al., 2015); } \\
\text { (Tukker, 2015); (Lieder and Rashid, 2016) }\end{array}$ \\
\hline B10 & $\begin{array}{l}\text { Lack of IT implementation for } \\
\text { communication and coordination }\end{array}$ & $\begin{array}{l}\text { (Wilson, 2007); (Luthra et al. 2011); (Khan } \\
\text { and Qianli, 2017) }\end{array}$ \\
\hline B11 & $\begin{array}{l}\text { Lack of producer's responsibility } \\
\text { B12 }\end{array}$ & $\begin{array}{l}\text { (Gunasekaran and Spalanzani 2012); } \\
\text { (Lorek and Spangenberg 2014) }\end{array}$ \\
\hline B13 & $\begin{array}{l}\text { Lack of government regulations and } \\
\text { legislative framework }\end{array}$ & $\begin{array}{l}\text { (Whiteman et al., 2013); (Long et al., } \\
\text { 2016); (K Muduli and Barve, 2011), } \\
\text { (Mathiyazhagan et al., 2013); (Tanner and } \\
\text { Kast 2003); (Bunse et al. 2011); (Almeida } \\
\text { et al. 2013); (Govindan et al. 2014); (Blok } \\
\text { et al. 2015); (Lieder and Rashid, 2016); } \\
\text { (Prieto-Sandoval et al., 2018) }\end{array}$ \\
\hline B14 & $\begin{array}{l}\text { Low demand for green textile products } \\
\text { (Govindan et al. 2014); (Lehtoranta et al. } \\
\text { from customers due to lack of awareness } \\
\text { 2011); }\end{array}$ & $\begin{array}{l}\text { (Govindan et al. 2014); (Luthra et al. } \\
\text { 2014); }\end{array}$ \\
\hline B15 & $\begin{array}{l}\text { Lack of promotion of sustainable products } \\
\text { (Lorek and Spangenberg 2014); (Jones et } \\
\text { al. 2011); (Khan and Qianli, 2017) }\end{array}$ \\
\hline
\end{tabular}

\section{Research method}

276 The research data for this study was collected through the questionnaire survey method, based 277 on the barriers to GSCMP adoption in textile industries listed in Table 1. Hierarchical cluster 278 analysis technique was employed to examine the survey data. The result of this research was then 279 verified and interpreted through experts' inputs.

280 The survey questions related to barriers encountered in GSCMP adoption and opinions on the 281 importance of each barrier. First of all, we develop a pre-test instrument for pilot testing, and after 282 consultations with academic and industry experts, we develop the final questionnaire on the basis 283 of five-point Likert scale ranging 1 (Negligible) to 5 (Very Important). A Likert scale was used to 284 measure respondents' attitudes by assigning numerical values on the significance of each barrier. 
Likert scales are the most universal and easily understood method for gathering opinion on the significance level of the barriers (Zhang et al., 2012). Each expert who participated in the survey was asked to rate the barriers from 1 to 5 based on their linguistic representation. Linguistic representations exhibit the level of significance by assigning numeric values as presented in Table 2.

Table 2: Numeric values for linguistic representation of the level of significance

\begin{tabular}{|c|c|}
\hline $\begin{array}{c}\text { Linguistic representation of level } \\
\text { significance }\end{array}$ & Numeric Values \\
\hline Negligible (N) & 2 \\
\hline Not Important (NI) & 3 \\
\hline Common (C) & 4 \\
\hline Important (I) & 5 \\
\hline Very Important (VI) & 1 \\
\hline
\end{tabular}

Opinions from professionals of textile industries in Bangladesh regarding the barriers to green 293 supply chain initiatives were gathered through both emailed and on-site questionnaire surveys.

294 Data collection methods incorporating both mailed and on-site survey generates a better result 295 (Zhu et al., 2008). The on-site survey helped reduce misinterpretation of questions and the mailed 296 survey helped gather adequate responses and reduce bias from the on-site survey.

297 The most common method of evaluating barriers is to compare the relative significance of 298 individual barriers by the mean value (Zhang et al., 2012), and the most significant barrier is the 299 one having the highest mean value. In this method, barriers are generally classified into three 300 categories: strong, common, and weak. The barriers only in the strong category are given further 301 attention. However, the main problem with this mean value method is that it ignores the 302 distribution of the respondents' opinion and fails to interpret the reasons for the divergence of 303 opinions from one respondent to another, and so an important barrier may be considered to be 304 negligible. For example, if a barrier is rated as 'strong' by half of the respondents and 'weak' by 305 the other half of the respondents, then according to the mean value method, the barrier will fall 306 into 'common' category. However, the barrier is critical (strong) to half of the respondents. 
Therefore, it is not wise to ignore the barriers although it is classified as 'common' based on the 308 mean value approach.

309 To mitigate this weakness of traditional mean value approach, this study employed hierarchical 310 cluster analysis technique in analyzing the barriers (Harloff et al., 2013). Cluster analysis is a 311 technique of grouping similar objects in the same cluster, while dissimilar objects are grouped into 312 different clusters (Kaufman and Rousseeuw, 2009). Hierarchical cluster analysis technique groups 313 the barriers from two perspectives: the relative importance of the barrier on green supply chain 314 practice, and the difference of opinion among respondents about the same barrier. Since the 315 differences of opinions among respondents are considered in this technique, the results derived 316 from this method is considered valid and highly reliable. Thus, this study used this technique in 317 analyzing the barriers of GSCMP in the textile industry of Bangladesh.

318 The resulting clusters of barriers were verified and interpreted through the opinions of experts' 319 who contributed on the survey, consisting of managers and consultants in operational and supply 320 chain divisions of leading textile and garment manufacturing companies in Bangladesh. Since 321 combining quantitative and qualitative methods gives a better understanding of the analysis (Clark, 322 2007), an insightful discussion on our findings is drawn in section 6 considering both the relative importance and divergence of the experts' opinion.

\section{Data survey}

A rigorous survey conducted involving professionals from different textile companies in Bangladesh through email and on-site questionnaire. In a hierarchical cluster analysis the sample size requirements mostly depend on the number of items (i.e., barriers of green supply chain) to be analyzed (Harloff et al., 2013). While the responses from 15 to 25 participants are considered sufficient for generating acceptable results for researches with 15 to 20 items in hierarchical cluster analysis, a sample size up to 35 could provide further safety of claiming the validity of the results (Harloff et al., 2013). Given that total 15 green supply chain barriers are analyzed in this study, responses are collected data from 30 participants. The on-site survey was conducted involving 15 professionals, who have 10-15 years of experience in managing operations and supply chains, related to the textile industry. To achieve sufficient responses and to increase the coverage of respondents, emailed surveys were also conducted, which involved an additional 15 managers having 10-15 years of experience in managing operations and supply chains in the textile industry. 
This combined method of getting respondents' opinions increased sample size and reduced the possibility of getting bias responses in one method of administering survey (Nulty, 2008). In total, we received 30 responses including 16 from SMEs from both methods of survey. Table 3 shows the respondents' opinions on the significance of each barrier.

Table 3: Total responses for each barrier on their level of significance

\begin{tabular}{|c|c|c|c|c|c|}
\hline \multirow[t]{2}{*}{ Barriers } & \multicolumn{5}{|c|}{ Level of Significance } \\
\hline & $\mathrm{N}$ & NI & $\mathrm{C}$ & I & VI \\
\hline B1 & 0 & 1 & 6 & 13 & 10 \\
\hline B2 & 0 & 2 & 3 & 18 & 7 \\
\hline B3 & 0 & 1 & 14 & 10 & 5 \\
\hline B4 & 0 & 1 & 9 & 15 & 5 \\
\hline B5 & 1 & 1 & 5 & 9 & 14 \\
\hline B6 & 1 & 3 & 13 & 11 & 2 \\
\hline B7 & 0 & 2 & 8 & 15 & 5 \\
\hline B8 & 0 & 1 & 7 & 12 & 10 \\
\hline B9 & 0 & 2 & 15 & 11 & 1 \\
\hline B10 & 1 & 2 & 14 & 10 & 3 \\
\hline B11 & 0 & 3 & 9 & 11 & 7 \\
\hline B12 & 0 & 1 & 11 & 14 & 4 \\
\hline B13 & 0 & 2 & 7 & 16 & 5 \\
\hline B14 & 0 & 1 & 6 & 19 & 4 \\
\hline B15 & 2 & 3 & 7 & 14 & 4 \\
\hline
\end{tabular}

\section{Data analysis}

343 For the analysis of the data, we applied a hierarchical clustering analysis technique.

\section{$344 \quad 5.1$ Fundamentals of Hierarchical Clustering}

345 In hierarchical method, the similar objects are clustered based on different criteria and clusters 346 are represented by a dendrogram (Farrelly et al., 2017). Guo (2003) specified three criteria, namely 347 distance-based, model-based, and density-based, to be used to cluster the objects. In this article, 348 we use Euclidean distances between the barriers to construct the dendrogram. Each layer of the 349 dendrogram represents a cluster.

350 Selected barriers are represented by $X_{i} ;(i=1,2,3, \ldots \ldots \ldots, m)$ and are set apart by their 351 relative importance value (RIV) $\left(X_{R I V}\right)$ and standard deviation value (SDV) $\left(X_{S D V_{i}}\right)$ with the help 352 of following equations, 


$$
X_{S D V_{i}}=\sqrt{\frac{\sum_{j=1}^{n}\left(u_{j}-X_{R I V i}\right)^{2}}{n}}
$$

356 Where $u_{j}$ represents the score given to barrier $X_{i}$ by participant $j ; \mathrm{n}$ is the total number of 357 responses received. These two variables are given equal importance through a standardization 358 process (Kaufman and Rousseeuw, 2009). The formulas for the process are shown below:

$$
\begin{aligned}
& \mu_{X_{R I V}}=\frac{1}{m} \sum_{i=1}^{m} X_{R I V_{i}} \\
& \mu_{X_{S D V}}=\frac{1}{m} \sum_{i=1}^{m} X_{S D V_{i}} \\
& Z\left(X_{R I V_{i}}\right)=\frac{X_{R I V_{i}}-\mu_{X_{R I V}}}{\frac{1}{m} \sum_{i=1}^{m}\left|X_{R I V_{i}}-\mu_{X_{R I V}}\right|}
\end{aligned}
$$

$$
Z\left(X_{S D V_{i}}\right)=\frac{X_{S D V_{i}}-\mu_{X_{S D V}}}{\frac{1}{m} \sum_{i=1}^{m}\left|X_{S D V i}-\mu_{X_{S D V}}\right|}
$$

364 between the pairs are grouped together, then the clusters having multiple barriers are formed. 365 Furthermore, the distance between each primary group is measured using group linkage average proposed by Kaufman and Rousseeuw (2009). If $p$ and $q$ are two barriers, and P and Q are two 367 initial cluster groups, then Euclidean distance $(d)$ between $p$ and $q$, and group average linkage (c) between cluster $P$ and cluster $Q$ can be calculated by the following formulas:

$$
d(p, q)=\sqrt{\left(Z\left(X_{R I V_{p}}\right)-Z\left(X_{R I V_{q}}\right)\right)^{2}+\left(Z\left(X_{S D V_{p}}\right)-Z\left(X_{S D V_{q}}\right)\right)^{2}}
$$

$$
c(P, Q)=\frac{1}{|P \| Q|} \sum_{\substack{q \in Q\\}} d(p, q)
$$

Here, $|P|=$ no. of barriers in cluster $P$

$$
|Q|=\text { no. of barriers in cluster } Q
$$


Equations (7) and (8) are repeated to reduce the number of clusters to a defined value. The 374 optimum number of clusters can be determined from the Silhouette index proposed by Rousseeuw 375 (1987). The formula to calculate Silhouette index is formulated as:

$$
s(i)=\frac{b(i)-a(i)}{\max \{b(i), a(i)\}}
$$

$$
s(i)= \begin{cases}1-\frac{a(i)}{b(i)} ; & \text { if } a(i)<b(i) \\ 0, & \text { if } a(i)=b(i) \\ \frac{b(i)}{a(i)}-1 ; & \text { if } a(i)>b(i)\end{cases}
$$

378 Therefore, from the above definition Silhouette value is limited in between $[-1,1]$ and can be 379 written as,

$$
-1 \leq s(i) \leq 1
$$

381 where, $a(i)$ is the mean distance for an individual barrier calculated one vs. all barriers in the same 382 cluster, $b(i)$ is the average distance between a barrier $i$ and other barriers in the clusters within 383 which $i$ is not contained. The number of clusters that gives the maximum value of $s(i)$ is taken as 384 the optimum number of clusters (Rousseeuw, 1987).

\section{$385 \quad 5.2$ Interpretation of results}

386 Data presented in Table 3 have been applied to Equations (1)-(6) to get the values of $387 X_{R I V}, X_{S D V}, Z\left(X_{R I V}\right)$ and $Z\left(X_{S D V}\right)$ and the values are shown in Table 4.

Table 4: Values of data characterization and standardization

\begin{tabular}{|l|l|l|l|l|}
\hline Code & \multicolumn{1}{|c|}{$\boldsymbol{X}_{\boldsymbol{R} \boldsymbol{V} \boldsymbol{V}}$} & \multicolumn{1}{|c|}{$\boldsymbol{X}_{\boldsymbol{S D V}}$} & $\boldsymbol{Z}\left(\boldsymbol{X}_{\boldsymbol{R I V}}\right)$ & $\boldsymbol{Z}\left(\boldsymbol{X}_{\boldsymbol{S D V} \boldsymbol{V}}\right)$ \\
\hline B1 & 1.564 & 1.632 & 1.366 & 1.382 \\
\hline B2 & 1.538 & 1.600 & 1.089 & 0.996 \\
\hline B3 & 1.397 & 1.472 & -0.434 & -0.578 \\
\hline B4 & 1.462 & 1.523 & 0.259 & 0.046 \\
\hline B5 & 1.590 & 1.701 & 1.643 & 2.220 \\
\hline B6 & 1.282 & 1.382 & -1.680 & -1.679 \\
\hline B7 & 1.449 & 1.521 & 0.120 & 0.030 \\
\hline B8 & 1.551 & 1.624 & 1.228 & 1.288 \\
\hline B9 & 1.269 & 1.349 & -1.819 & -2.074 \\
\hline B10 & 1.308 & 1.408 & -1.403 & -1.363 \\
\hline B11 & 1.436 & 1.537 & -0.018 & 0.218 \\
\hline
\end{tabular}




\begin{tabular}{|l|l|l|l|l|}
\hline B12 & 1.423 & 1.484 & -0.157 & -0.425 \\
\hline B13 & 1.462 & 1.531 & 0.259 & 0.148 \\
\hline B14 & 1.487 & 1.533 & 0.536 & 0.172 \\
\hline B15 & 1.346 & 1.488 & -0.988 & -0.381 \\
\hline
\end{tabular}

390 For example, we used the responses given to barrier B1 from Table 3 and applied it to Equation 391 (1) to get the value of its relative importance $\left(X_{R I V}\right)$ which is found to be 1.564. Similarly Equations 392 (2)-(6) are used to get the values of $X_{S D V}, Z\left(X_{R I V}\right), Z\left(X_{S D V}\right)$ which are accordingly 1.632, 1.366, 393 and 1.382. The same process was followed to generate the other values of Table 4. In Table 4, the 394 negative values of $Z\left(X_{R I V}\right)$ and $Z\left(X_{S D V}\right)$ means that they are located on the left side of the mean 395 value and the positive values of $Z\left(X_{R I V}\right)$ and $Z\left(X_{S D V}\right)$ means that they are located on the right side 396 of the mean value. As we have almost equal numbers of $Z\left(X_{R I V}\right)$ and $Z\left(X_{S D V}\right)$ values for both 397 right and left side of the mean, we can say that the data is well distributed in the normal distribution 398 curve.

399 A complicated computation process was involved in applying hierarchical cluster analysis to 400 Equations (7) and (8). Therefore, this computation process was done using MATLAB, a high401 performance language for computing. The results are shown in a dendrogram presented in Figure 402 1 . 


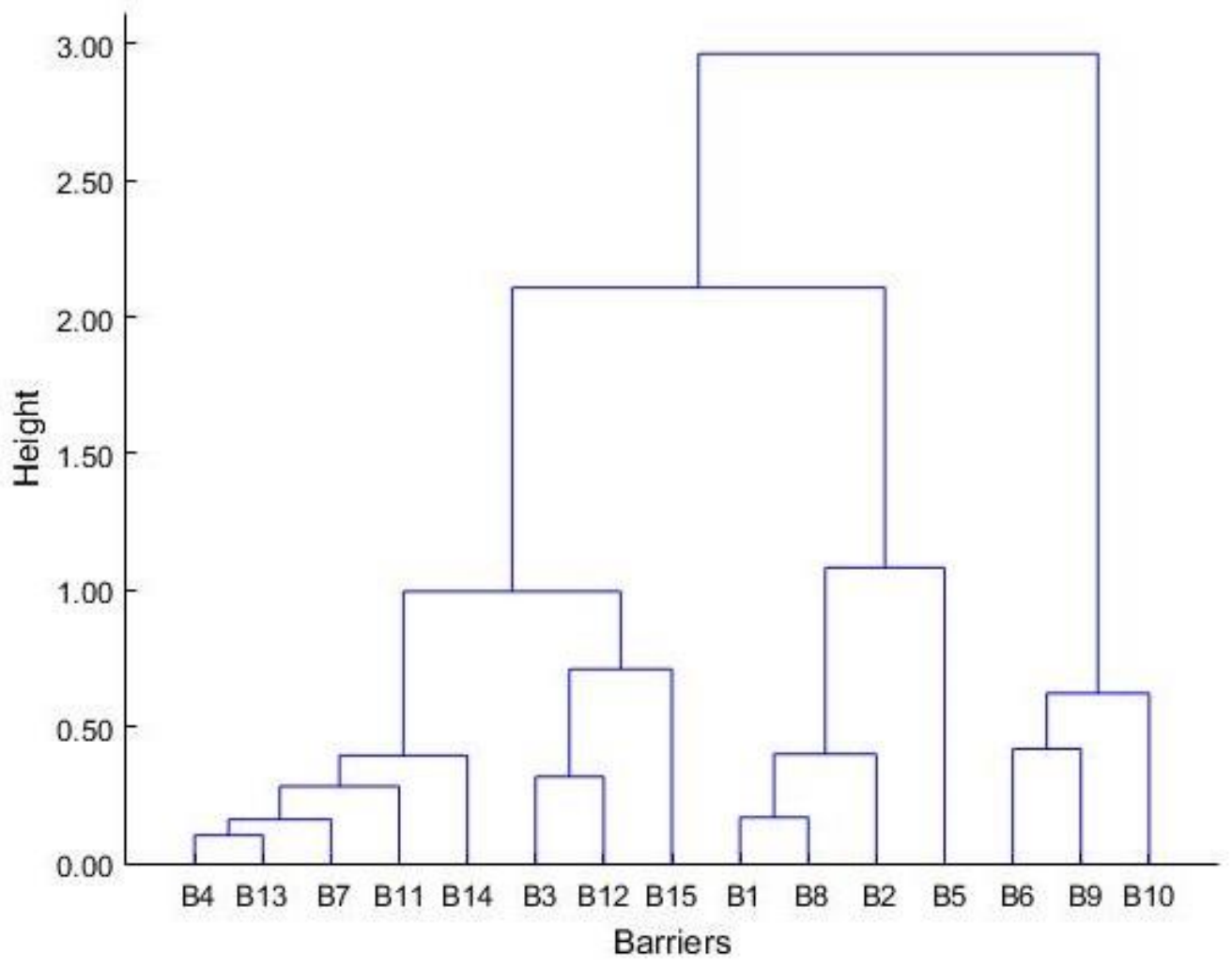

405 In Figure 1, it is seen that if the cut-off point is at height 0.65 then we get six clusters. The first 406 one is comprised of B4, B13, B7, B11, and B14; the second one is comprised of B3 and B12; the 407 third one is comprised of B15; the fourth one is comprised of B1, B8, and B2; the fifth one is 408 comprised of B5; and the sixth cluster is comprised of B6, B9, and B10. It should be mentioned 409 that all samples clustered below a particular level of distance will have inter-sample dissimilarities 410 less than that level. In the next step we calculated the Silhouette index for finding the optimum 411 number of clusters, which was found to be six clusters, similar to the results of the dendrogram.

413 In order to get best clustering performance, we need to find the optimum number of clusters in 414 our dataset. For this, we calculated the Silhouette indexes using Equation (9). Silhouette can be 415 used to find the consistency of the clustering data and enables us to visualize the optimum number 416 of clusters in 2D space. The results are presented in Figure 2. 


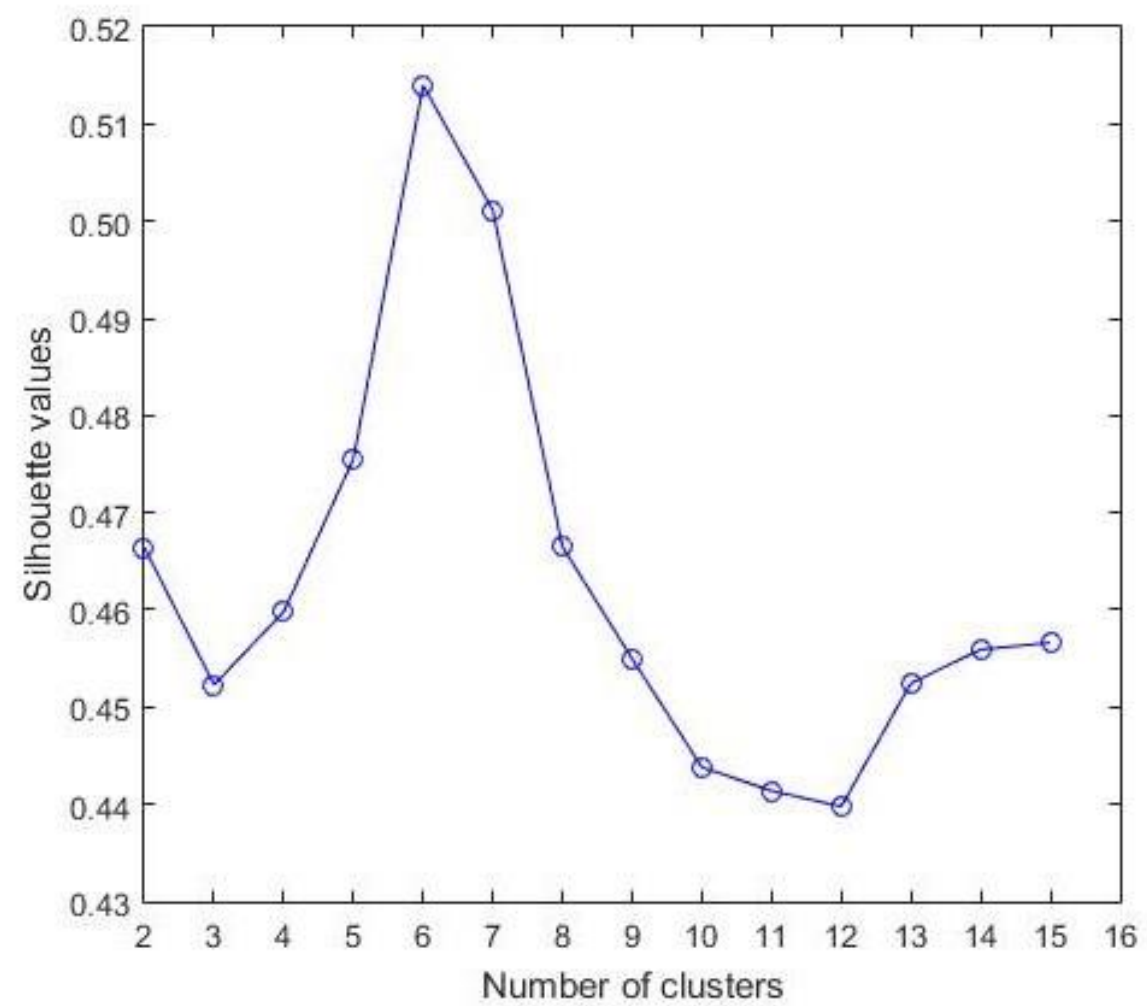

Figure 2: Values of Silhouette index

419 As presented in Figure 2, the optimum number of clusters is 6, where Silhouette index has the 420 maximum value (0.515). This is the optimum number of clusters for generating perfect clustering 421 results. The six clusters are presented in Figure 3 in a two-dimensional plot where $Z\left(X_{R I V}\right)$ is the 422 ordinate and $Z\left(X_{S D V}\right)$ is the abscissa. 


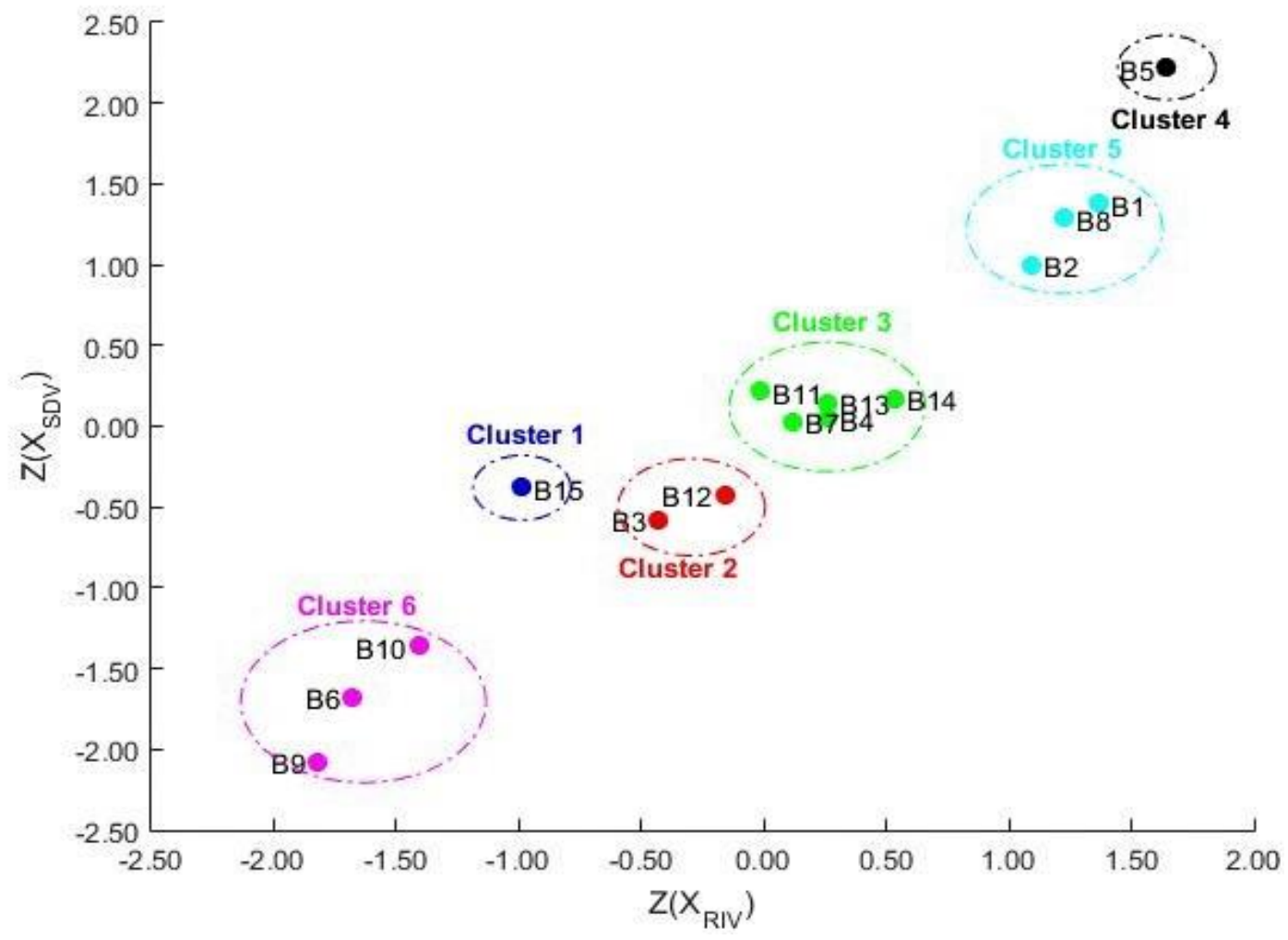

B2 Lack of collaboration due to complexity

B3 Lack of incentives from the government

B4 Lack of effective efforts of stakeholders

B5 Financial constraints

B6 Unskilled workforce

B7 Organizational culture resistance to change

B8 Lack of top management commitment

B9 Lack of third parties to recollect used products

B10 Lack of IT implementation

B11 Lack of producer's responsibility

B12 Technological obstructions

B13 Lack of government regulations

B14 Low demand from customers

B15 Lack of promotion of sustainable products

\section{Figure 3: Clusters in the two-dimensional plot}

430 It is visible that Cluster 1 containing GSCMP barrier B15 has a relatively low value of $X_{R I V}$ and

431 an average level of $X_{S D V}$, indicating that respondents were consistent in finding out that the

432 influence of the barrier within this cluster is relatively low. Cluster 2, comprising B3 and B12, has

433 a descent level of $X_{R I V}$ and $X_{S D V}$, meaning that the impact of the barriers in this cluster is more or

434 less the same. Cluster 3, comprising five barriers, has a relatively high level of $X_{R I V}$ and $X_{S D V}$, 435 meaning that the importance of the barriers within this cluster is relatively high, with some 
436 variation in the opinions of the respondents. Cluster 4 is comprised of barrier B5 and has the 437 highest value of $X_{R I V}$ and the highest value of $X_{S D V}$, meaning that Cluster 4 is considered as the 438 most significant barrier cluster, but with noticeable differences in views among respondents.

439 Cluster 5, comprising three barriers, has the second highest value of $X_{R I V}$ and the second highest 440 value of $X_{S D V}$, indicating that Cluster 5 is considered as a very impactful barrier cluster, but 441 respondents have very distinctive views among themselves about its importance. Cluster 6 has the

442 lowest value of $X_{R I V}$ and $X_{S D V}$, indicating that the respondents agreed that the barriers in this cluster 443 have the lowest importance.

\section{Discussion and implications}

445 This study aims at answering the question of what the barriers of GSCMP in the textile industry 446 in emerging countries like Bangladesh are and how the practitioners opine their criticality. 447 Through answering this research question, it contributes to the literature and help the practitioners 448 and policy makers in strategy formulation. This section discusses the results of the study and 449 implications and theoretical contributions of the study findings.

\subsection{Discussion}

451 Indicating 15 barriers within the 6 clusters, the most significant barriers towards GSCMP 452 adoption in the textile industry in Bangladesh can be found. It is found that respondents agreed 453 that barriers in clusters 1, 2, and 3, with high RIV and relatively low SDV, are critical barriers to 454 GSCMP adoption. High relative importance and relatively low variance in cluster 1, 2 and 3 455 enables us to decide that the barriers within these clusters are most important barriers in GSCMP 456 adoption in the context of textile industries in Bangladesh. Practitioners shed distinctive views on 457 the importance of the barriers in clusters 4 and 5.

\section{$458 \quad$ 6.1.1 The consensus}

459 The barrier "low demand of green textile products from customers due to lack of awareness" in 460 Cluster 3 is considered to be a very critical barrier by most of the practitioners. This result suggests 461 that consumers' purchasing decisions for textile products in Bangladesh are mainly affected by 462 price, quality, and durability, rather than the green features of the textile products. Therefore, low 463 customer demand for green textile products significantly lowers practitioners' keenness for 464 implementing green supply chain initiatives. The findings are also supported with previous studies 
conducted by (Khan and Qianli, 2017), and (Khosla, 2009) highlight that buyers of developing

466 countries are more price sensitive as compare to developed countries, which negatively associated 467 with the adoption of GSCMP.

468 In this study, "less incentives from the government" is found as another critical barrier, which hinders the adoption of GSCMP in the textile industry of Bangladesh. A plausible explanations of

470 this result is that there are not enough incentives to encourage practitioners to promote and engage 471 a green manufacturing processes in Bangladesh, although special benefits by awarding green 472 buildings, such as Leadership in Energy and Environmental Design (LEED) exists (GBIG, 2017). 473 Another possible explanation is that the existing incentive policies fail to bear the additional cost 474 of adopting green processes, which discourages the practitioners to adopt GSCMP. Although 475 conducted in the context of garment industry of Bangladesh, the result is consistent with that of 476 (Anisul Huq et al., 2014) who highlight that incentives from government through different 477 subsidies on green materials/products while embossing heavy financial penalties on polluting 478 practices are needed to increase the adoption of GSCMP. This scenario is also consistent with 479 other studies conducted in the context of other emerging economies (Blok et al., 2015); (Nazzal et 480 al., 2013). For example, Majumdar and Sinha (2019) find that financial incentives from the 481 government, such as financial rewards or private-public investments to improve green capabilities, 482 are effective in motivating the practitioners of emerging countries of Southeast Asia to adopt 483 GSCMP.

484 "Lack of government regulations and legislative framework" is another crucial barrier accepted 485 by all practitioners in Bangladesh. Consistent with the findings of Lettenmeier et al. (2012), this 486 result suggests that legislative framework is necessary for ensuring a supportive business 487 environment to implement GSCMP initiatives by undertaking strategic policy frameworks. As a 488 result, many countries, including developing countries, already take appropriate legislations to 489 increase the adoption of GSCMP. For example, Majumdar and Sinha (2019) report that in April 490 2015, Indian Government have passed a legislation for those textile manufacturers which discharge $49125 \mathrm{KL}$ or more water per day. The legislation stated that those manufacturers must conform to zero 492 liquid discharge norms by building effluent treatment plants and using multi-effect evaporators 493 and reverse osmosis. The result also means that in developing countries like Bangladesh, due to 494 lack of government rules and regulations in adopting eco-friendly process, the textile industrialists 
495 are reluctant to introduce sustainable production processes. As a result, in spite of being a major 496 income source for the national economy, Bangladesh's textile industry is lagging behind in 497 sustainability.

498 "Lack of promotion of green textile materials in the local market" is also perceived as critical 499 barrier to adopt GSCMP initiatives in the Bangladeshi textile industry. The result suggests that 500 green textile materials are rare in Bangladesh, thus local dealers purchase green textile materials 501 from other countries where green textile materials are more available. The main reasons why 502 unavailability of local green materials hinders the adoption of GSCMP is that the cost of sourcing 503 increases when manufacturers source from overseas, such as importing from European and 504 Western countries. For example, purchasing of green materials from overseas incur a huge cost in 505 the supply chain systems through different heavy import duties, transportation cost, long lead-time 506 and insurance cost (Islam et al., 2018). Similar findings also noted in the context of the other 507 emerging countries, which further strengthen the results of this study. For example, (Khan and 508 Qianli, 2017) conduct a research on the green supply chain practices in the context of Pakistan and 509 their results confirm that due to a scarcity of green material in the local market, firms are avoiding 510 to adopt green supply chain practices into their manufacturing processes.

511 "Technical obstructions with implementing GSCMP” is also another significant barrier for 512 textile industry of Bangladesh. This result suggests that some green textile processes require 513 machinery that cannot be operated by an untrained workforce. Moreover, the result means that to 514 make the whole supply chain greener, changing the whole infrastructure including the 515 transportation medium is also needed. One government document (Alam, 2009) indicates that most 516 of the aged industries in Bangladesh do not have treatment facilities and, therefore, they tend to 517 unload industrial, untreated effluents into the water bodies of the country. Studies have already 518 pointed out that textile dyeing and printing industries unload harmful effluents into water bodies 519 (Choudhury, 2017). The Asian Development Bank report (ADB, 2008) suggested the need for 520 determining treatment technologies that are economical for the most harmful and polluting 521 industries. Therefore, the technical problems associated with green supply chain discourages the 522 textile practitioners to adopt GSCMP. The results are also supported by previous studies 523 (Govindan et al., 2014); (Barua and Ansary, 2017) conducted in India and Bangladesh, 524 respectively. Their findings highlighted that due to the lack of green technology and expertise in 
Asian emerging economies, firms poorly dumbed their industrial untreated effluents into the soil

526 and/or unloaded into the nearest river/canals, which not only destroy to the fauna and flora lives

527 but also create several human-related diseases (Khan and Qianli, 2017).

\section{$528 \quad$ 6.1.2 Opinions divergence}

529 "Financial constraints" is found to be a major obstacle in adopting the GSCMP in textile 530 industries of Bangladesh with opinions divergence. (Khan et al., 2016) and (Khan and Qianli, 2017) 531 explore in the context of emerging economies that firms are afraid to adopt GSCM processes and 532 green practices due to huge investment required. However, finding of this study indicates that all 533 firms do not perceive this barrier in the same manner as we found divergence in opinions. As Lee 534 (2008) reported, this barrier is more critical for the practitioners of SMEs since they deemed 535 additional costs as a vital barrier since the investment on GSCMP can be significant and ruin their 536 financial performance. On the other hand, large firms may not perceive this as a major barrier 537 because they suffer less from resource constraints. This observation is consistent with the findings 538 of Besbes et al. (2013) that large firms are unwilling to implement GSCMP mainly because of 539 their unawareness of the concepts of life cycle costs and they focus on short term financial 540 performance, rather than resource constraints.

"Lack of top management commitment" and "organizational culture resistance to change" are 542 two other critical barriers for GSCMP adoption. While the results of previous studies (e.g., Zhu 543 and Geng, 2013) generalize this barriers in the context of all companies and indicate that top 544 management of all firms are not committed and supportive towards eco-friendly processes because 545 they focus on short-term financial returns and resist to change, the result of this study shows the 546 divergence in opinions on this barrier. Such a difference in the findings reflects that the level of 547 internal commitment is not same across all the firms. Probably SMEs consider this as a severe 548 obstacle since they generally lack a strategic plan in adopting GSCMP (Lee, 2008). However, this 549 scenario may not be same for leading companies who would like to invest more for making 550 processes greener to improve their brand image and competitive advantage.

551 The result also shows that "lack of collaboration among supply chain partners due to complex 552 supply chain" is also a critical barrier although the opinions varied. This observation exactly 553 echoes the result of Zhu et al. (2017) who report that without the presence of relational governance 554 GSCM fail to improve business performance, therefore, firms do not show interest in adopting 
GSCMP when there is a lack of collaboration. This barrier may be more crucial for the textile

556 firms having less experience. It is because they generally fail to maintain long-term association with eco-friendly suppliers and their suppliers are reluctant to share the quality performance of their products (Lee et al., 2012). On the other hand, leading companies have a strong relationship with their suppliers. As a result, they can get information from their suppliers about the performance and effects of their textile materials, therefore, may not consider this barrier as a critical one. While there is an opinion divergence, consistent with the findings of previous studies (AlKhidir and Zailani, 2009); (Luthra et al., 2011), the result of this study also shows that IT implementation within the organization is required to keep track of both forward and backward flow of materials and other resources for greening the supply chain efficiently.

"Lack of attention to developing theories and grounded research in the context in GSCMP implementation" is a hurdle encountered with great importance but with some opinion divergence.

567 This means that while practitioners who want to learn about GSCMP in their context, they see less 568 investigation is done in the textile industry of emerging economies like Bangladesh and, therefore, 569 struggle to find the relevant research. However, as suggested in previous studies (Diabat and 570 Govindan, 2011); (Zhu et al., 2008), companies only who are conscious of their environmental 571 impacts feel the need for in-depth research that analyzes the barriers encountered in GSCMP 572 implementation. The respondents who perceive this barrier is not a critical one for GSCMP 573 probably ignore the need of learning from empirical investigation and focus more on financial 574 capabilities and governmental supports.

\section{$575 \quad 6.2$ Implications of the findings}

576 Using the opinions of 30 respondents in the textile industry of Bangladesh, this study reveals 577 that while some of the barriers of adopting GSCMP are critical to all firms (opinion consensus) 578 others are only crucial for few firms (opinion divergence). This difference means that firms in the 579 textile industries of the emerging countries face numerous but diverse obstacles. This also means 580 that same strategies for all firms may not provide desired outcomes in improving the GSCMP of 581 entire industry. While same strategies can be taken to overcome the opinion consensus barriers, 582 different strategies for opinion divergence barriers are needed. 
Among the consensus barriers, this study finds that low demand of green textile products from customers are the most critical barriers. Therefore, proper strategies are needed to improve the awareness levels of the customers. While involving with a contract with the foreign buyers, textile firms can discuss and encourage the buyers to buy green products. In this regard, they also can highlight the long-term benefits of green products and how GSCMP is related with the image of the seller (Ageron et al., 2012). Both textile firms and policy makers of the industry, such as government, can implement appropriate campaigns to improve the awareness of local buyers. Educating customers about the environmental impact of the industries will make them aware of green supply chain process, resulting in greater customer demand for sustainable products. For example, governmental bodies can build consumer awareness on green products and their advantages on their atmosphere through different TVs commercials, signboards, and environmentally friendly training (Khan et al., 2019). In addition to campaigns to improve awareness levels of buyers, government of emerging countries such as Bangladesh should also introduce proper incentives to encourage the textile manufacturers to implement GSCMP as this is also found as another barrier. In this regard, the government can implement green taxation and subsidization to motivate the manufacturers within the country to adopt GSCMP, as these are found effective by Sheu and Chen (2012). The government of developing countries can also 600 implement strategic incentive policies, such as financial rewards, by learning from the developed countries, as they already have such incentives in place (Koebel et al., 2015). In order to ensure

602 that a good portion of textile manufacturers are practicing GSCMP, the government also need to 603 formulate strict environment friendly policies to protect green industries/projects for better socioenvironmental sustainability. Moreover, government must need to ensure that the green materials are available in the local market as the practitioners think this is also a crucial barrier. The

606 Bangladeshi government can provide some tax benefits or waive the registration fees for the business who involve in supplying green materials.

608 For the convergence barriers of adopting GSCMP, it is important to differentiate which group opine a barrier as critical and which group not. This is important since it will lead to understand

610 why this barrier is perceived as critical by some but not by all. Then appropriate strategies need to 611 be formulated by considering the specific group that rated the barrier as critical so that they also 612 can tackle. Among the divergence barriers, most critical one is found as financial constraints. 613 Obviously, this financial issue is more critical for SMEs due to their lack of financial resources 
614 (Chowdhury et al., 2019). Similarly, SMEs generally have lack of top management commitment 615 in implementing GSCMP. For example, around one-fifth of the Bangladeshi SMEs do not have 616 environmental clearance and more than 50 per cent are not familiar with the green practices such

617 as using renewable energy (Bangladesh SME Foundation, 2013). Since Lee et al. (2012) have 618 already found that GSCMP positively impact the business performance of SMEs, practitioners of 619 SMEs need to commit and invest for the improvement of green supply chain infrastructure. 620 GSCMP can provide long-term benefits to SME practitioners, which will make up the high initial 621 cost of GSCMP implementation. However, they need to ensure that their scarce financial resources 622 are used efficiently so that it does not immediately impact other activities of the firms. Even large 623 firms, who do not have resource constraints, need to invest carefully and efficiently to achieve the 624 maximum benefits of GSCMP. In order to tackle the barriers of GSCMP, practitioners, especially 625 less expensive group, also need to focus on improving collaboration with their supply chain 626 partners such as buyers and suppliers. This is because the respondents of Bangladeshi textile 627 industry noted this as a crucial barrier. On the other hand, a proper GSCMP is only possible when 628 there is good coordination among the players within a supply chain (Zhu et al., 2017). In this 629 regard, the practitioners can focus on leveraging social capital, which a recent study (Chowdhury 630 et al., 2019) in the context of Bangladesh apparel industry finds very effective.

631 Looking at several barriers that require actions from the government, it can be inferred that 632 practitioners perceive having several governmental supports as a precondition of implementing 633 GSCMP. This is probably why (Khan and Qianli, 2017) argue that the green market cannot survive 634 without governmental protections and supports. Therefore, policy makers should not expect 635 managers to adopt environmental- friendly processes without implementing a strong regulatory 636 system. This study also suggests a combined effort from policy makers, textile firms and their 637 supply chain players to tackle all the barriers of GSCMP effectively.

\section{$640 \quad 6.3$ Theoretical contributions}

641 This study makes several contributions to the theory. First, it contributes to the knowledge on green 642 supply chain in the context of emerging countries. While plenty of studies are available in the 
643 literature that discuss several issues on green supply chain, only a few researches are conducted in 644 the context of emerging economies, and specifically in the context of Bangladesh (Majumdar and 645 Sinha, 2019). The findings that are derived in the context of developed countries may not be 646 applicable to firms of the developing countries. Therefore, through investigating green supply 647 chain barriers in the context of an emerging country, this research supplements the inadequacy in 648 research in this regard. Second, this study reveals the barriers in adopting GSCMP in the context 649 of textile industries. In spite of being a major industrial sector, there is not enough research that 650 studies the barriers to GSCMP implementation in textile industry that considers issues of the 651 emerging economy context like Bangladesh (Nayak et al., 2019). Such a gap in research makes it 652 difficult to ensure an environment that encourages GSCMP adoption in the textile industry. This 653 study also supplements in this adequacy.

654 Third, this study does not merely explore the barriers, rather critically analyze them by using 655 hierarchical cluster analysis to provide most important barriers. Moreover, the findings empirically 656 confirm that there are some barriers that are common to all firms (consensus barriers) and that are 657 some that are specific to certain group (divergent barriers). This mean that a barrier of GSCMP 658 should not be generalized to all firms without proper analysis. Such a perspective is not explored 659 in the literature of green supply chain management and an original contribution of this study 660 (Oliveira et al., 2018). Finally, through the comprehensive discussion on results and implications, 661 this study sheds some light on the strategies for alleviating the barriers. For example, the study 662 found that less government incentive is a critical consensus barrier, and it also provide some 663 suggestions, based on literature survey, how to alleviate this barrier.

\section{Conclusions and future research scopes}

665 This study was conducted to create awareness among the textile practitioners of a developing 666 country like Bangladesh about the potential significance of greening the supply chain process, and 667 to identify the most critical barriers towards green supply chain implementation within the 668 Bangladeshi textile industry. This study incorporated a hierarchical cluster analysis technique in 669 order to identify the critical barriers and reveal the cause of opinion divergence among the 670 respondents. 
It is found that financial constraints, lack of top management commitment, and complexity in

672 supply chain are the most critical barriers for some of the practitioners, and lack of demand from

673 customers for sustainable products, weak government regulatory system, lack of promotion of

674 sustainable products, and technical obstructions are the commonly accepted important barriers

675 towards green supply chain adoption in the textile industry of Bangladesh. It is also found that

676 there are very few research projects undertaken within the textile industry of emerging economy

677 context to analyze the barriers in GSCMP adoption. As a result, lack of awareness prevails among

678 consumers, managers, policy makers and government bodies there.

679 This study will assist managers and relevant government bodies of developing countries towards 680 policy making and strategy development to mitigate the green supply chain adoption barriers. In 681 the future, studies can be carried out considering other industrial sectors or other countries' 682 scenarios to improve the generalizability of the findings. This study uses hierarchical cluster 683 analysis to analyze the data, which was collected via a questionnaire survey with 30 supply chain 684 professionals of the textile industry of Bangladesh. While the sample size of this study is adequate 685 to claim the validity of the results considering the nature of the study, yet a large-scale survey with 686 the textile manufacture could be undertaken in future to text the impact of major barriers on the 687 adoption of green supply chain. Such a study will benefit from two perspectives. First, this will 688 allow to investigate the causal relationships between barriers and adoption of green practices 689 empirically through using regression or structural equation modelling (Gimenez et al., 2005). This, 690 in turn, will enhance the generalizability of the results of this study. Second, this will allow to 691 further scrutinize the findings of this study by considering several demographic variables. For 692 instance, the findings of this study show that the low demand of customers for green products as 693 one of the main barriers of adopting green supply chain. However, buyers from developed 694 countries, such as USA and UK, are more environmentally conscious (Luthra et al., 2014) and, 695 hence, may prefer paying more for textiles manufactured using green processes and technologies. 696 Therefore, such a study will allow to investigate the moderating role of the location/origin of the 697 buyers in the relationship between low demand of customers and adoption of green supply chain 698 practices, which provide further insight about the relationship. Finally, a research to reveal why 699 there is a divergence in the opinions of the respondents regarding GSCMP will provide further 700 information, which will be helpful to formulate proper strategies for enhancing the adoption of 701 GSCMP. 


\section{References}

703

704

705

706

707

708

709

710

711

712

713

714

715

716

717

718

719

720

721

722

723

Abubakar, F.H., 2018. An investigation into the drivers, barriers and policy implications of circular economy using a mixed-mode research approach. University of Sheffield.

ADB, 2008. Managing Asian Cities: sustainable and inclusive urban solutions.

Ageron, B., Gunasekaran, A., Spalanzani, A., 2012. Sustainable supply management: An empirical study. Int. J. Prod. Econ. 140, 168-182.

Ahamed, F., 2013. Improving Social compliance in Bangladesh's Ready-made Garment Industry. Labour Manag. Dev. 13.

Ahmad, N., Hossen, J., Ali, S.M., 2018. Improvement of overall equipment efficiency of ring frame through total productive maintenance: a textile case. Int. J. Adv. Manuf. Technol. 94, 239-256.

Ahmed, F.Z., Greenleaf, A., Sacks, A., 2014. The Paradox of Export Growth in Areas of Weak Governance: The Case of the Ready Made Garment Sector in Bangladesh. World Dev. 56, $258-271$.

Akadiri, P.O., 2015. Understanding barriers affecting the selection of sustainable materials in building projects. J. Build. Eng. 4, 86-93.

Al Zaabi, S., Al Dhaheri, N., Diabat, A., 2013. Analysis of interaction between the barriers for the implementation of sustainable supply chain management. Int. J. Adv. Manuf. Technol. $68,895-905$.

Alam, G.J., 2009. Environmental pollution of bangladesh--it's effect and control. Pulp Pap. 51, $13-17$.

Alay, E., Duran, K., Korlu, A., 2016. A sample work on green manufacturing in textile industry. Sustain. Chem. Pharm. 3, 39-46.

Ali, S.M., Arafin, A., Moktadir, M.A., Rahman, T., Zahan, N., 2017. Barriers to Reverse Logistics in the Computer Supply Chain Using Interpretive Structural Model. Glob. J. Flex. Syst. Manag. 1-18.

AlKhidir, T., Zailani, S., 2009. Going green in supply chain towards environmental 
sustainability. Glob. J. Environ. Res. 3, 246-251.

730

731

732

733

734

735

736

737

738

739

740

Almeida, C.M.V.B., Bonilla, S.H., Giannetti, B.F., Huisingh, D., 2013. Cleaner Production initiatives and challenges for a sustainable world: an introduction to this special volume. J. Clean. Prod. 47, 1-10.

Angel, M., Subramanian, G., Muthu, S., 2015. Environmental footprints and eco-design of products and processes: Handbook of sustainable luxury textiles and fashion. Springer, Singapore.

Anisul Huq, F., Stevenson, M., Zorzini, M., 2014. Social sustainability in developing country suppliers. Int. J. Oper. Prod. Manag. 34, 610-638.

Araujo Galvão, G.D., de Nadae, J., Clemente, D.H., Chinen, G., de Carvalho, M.M., 2018. Circular Economy: Overview of Barriers. Procedia CIRP 73, 79-85.

Asgari, B., Hoque, M.A., 2013. A system dynamics approach to supply chain performance analysis of the ready-made-garment industry in Bangladesh. Ritsumeikan J. Asia Pacific Stud. 32, 51-61.

Bangladesh Economic Review, 2018. Bangladesh Economic Review. Economic Adviser's Wing Finance Division, Ministry of Finance, Government of the People's Republic of Bangladesh, Dhaka, Bangladesh.

Bangladesh SME Foundation, 2013. SME cluster in Bangladesh. Small and Medium Enterprise Foundation, Dhaka, Bangladesh.

Barua, U., Ansary, M.A., 2017. Workplace safety in Bangladesh ready-made garment sector: 3 years after the Rana Plaza collapse. Int. J. Occup. Saf. Ergon. 23, 578-583.

Berg, A., 2011. Not Roadmaps but Toolboxes: Analysing Pioneering National Programmes for Sustainable Consumption and Production. J. Consum. Policy 34, 9-23.

Berg, A., Hedrich, S., Kempf, S., Tochtermann, T., 2011. Bangladesh's ready-made garments landscape: the challenge of growth. McKinsey \& Company, Inc.

Besbes, K., Allaoui, H., Goncalves, G., Loukil, T., 2013. A green supply chain design with product life cycle considerations. Supply Chain Forum An Int. J. 14, 18-25. 
Beton, A., Dias, D., Farrant, L., Gibon, T., Le Guern, Y., Desaxce, M., Perwueltz, A., Boufateh, I., Wolf, O., Kougoulis, J., others, 2014. Environmental improvement potential of textiles (IMPRO-Textiles), European Commission.

Bhuiyan, A.J., Haq, M.N., 2008. Improving Occupational Safety and Health in Bangladesh. Int. J. Occup. Environ. Health 14, 231-233.

Biju, P.L., Shalij, P.R., Prabhushankar, G. V, 2015. Evaluation of customer requirements and sustainability requirements through the application of fuzzy analytic hierarchy process. J. Clean. Prod. 108, 808-817.

Blok, V., Long, T.B., Gaziulusoy, A.I., Ciliz, N., Lozano, R., Huisingh, D., Csutora, M., Boks, C., 2015. From best practices to bridges for a more sustainable future: Advances and challenges in the transition to global sustainable production and consumption: Introduction to the ERSCP stream of the Special volume. J. Clean. Prod. 108, 19-30.

Bunse, K., Vodicka, M., Schönsleben, P., Brülhart, M., Ernst, F.O., 2011. Integrating energy efficiency performance in production management - Gap analysis between industrial needs and scientific literature. J. Clean. Prod. 19, 667-679.

Carter, C.R., Rogers, D.S., 2008. A framework of sustainable supply chain management: moving toward new theory. Int. J. Phys. Distrib. Logist. Manag. 38, 360-387.

Cheng, P., Fu, Y., Lai, K.K., 2018. Supply chain risk management in the apparel industry, 1st ed, Routledge Advances in Risk Management. Routledge, London and New York.

Choudhury, A.K.R., 2017. Sustainable chemical technologies for textile production, in: Sustainable Fibres and Textiles. Elsevier, pp. 267-322.

Chowdhury, P., Lau, K.H., Pittayachawan, S., 2019. Operational supply risk mitigation of SME and its impact on operational performance: a social capital perspective. Int. J. Oper. Prod. Manag. 39, 478-502.

Clark, J.S., 2007. Models for ecological data: an introduction. Princeton university press Princeton.

Cooper, T., 2005. Slower consumption reflections on product life spans and the "throwaway 
society.” J. Ind. Ecol. 9, 51-67.

784 Diabat, A., Govindan, K., 2011. An analysis of the drivers affecting the implementation of green 785 supply chain management. Resour. Conserv. Recycl. 55, 659-667.

786 Diabat, A., Kannan, D., Mathiyazhagan, K., 2014. Analysis of enablers for implementation of 787 sustainable supply chain management - A textile case. J. Clean. Prod. 83, 391-403.

788 Dubey, R., Gunasekaran, A., Samar Ali, S., 2015. Exploring the relationship between leadership, 789 operational practices, institutional pressures and environmental performance: A framework 790 for green supply chain. Int. J. Prod. Econ. 160, 120-132.

791 Farrelly, C.M., Schwartz, S.J., Lisa Amodeo, A., Feaster, D.J., Steinley, D.L., Meca, A., 792 Picariello, S., 2017. The analysis of bridging constructs with hierarchical clustering 793 methods: An application to identity. J. Res. Pers. 70, 93-106.

794 Fontana, E., Egels-Zandén, N., 2018. Non Sibi, Sed Omnibus: Influence of Supplier Collective Behaviour on Corporate Social Responsibility in the Bangladeshi Apparel Supply Chain. J. Bus. Ethics.

Gaur, J., Mani, V., 2018. Antecedents of closed-loop supply chain in emerging economies: A conceptual framework using stakeholder's perspective. Resour. Conserv. Recycl. 139, 219227.

800 GBIG, 2017. GBIG- LEED certification, Bangladesh [WWW Document].

801 Gimenez, C., Large, R., Ventura, E., 2005. SCM research methodologies: employing structural 802 equation modeling, in: Research Methodologies in Supply Chain Management. Springer, pp. $155-170$.

804 Gold, S., Hahn, R., Seuring, S., 2013. Sustainable supply chain management in "Base of the Pyramid" food projects-A path to triple bottom line approaches for multinationals? Int. Bus.

807 Govindan, K., Hasanagic, M., 2018. A systematic review on drivers, barriers, and practices towards circular economy: a supply chain perspective. Int. J. Prod. Res. 56, 278-311.

809 Govindan, K., Kaliyan, M., Kannan, D., Haq, A.N., 2014. Barriers analysis for green supply 
chain management implementation in Indian industries using analytic hierarchy process. Int.

812 Green, K.W., Zelbst, P.J., Meacham, J., Bhadauria, V.S., 2012. Green supply chain management 813 practices: impact on performance. Supply Chain Manag. An Int. J. 17, 290-305.

814 Grimm, J.H., Hofstetter, J.S., Sarkis, J., 2014. Critical factors for sub-supplier management: A 815 sustainable food supply chains perspective. Int. J. Prod. Econ. 152, 159-173.

816 Gunasekaran, A., Spalanzani, A., 2012. Sustainability of manufacturing and services:

817 Investigations for research and applications. Int. J. Prod. Econ. 140, 35-47.

818 Guo, D., 2003. Coordinating computational and visual approaches for interactive feature 819 selection and multivariate clustering. Inf. Vis. 2, 232-246.

820 Haque, M.Z., Azmat, F., 2015. Corporate social responsibility, economic globalization and 821 developing countries. Sustain. Accounting, Manag. Policy J. 6, 166-189.

822 Harloff, J., Stringer, A., Perry, J., 2013. Sample size requirements for stable clustering of free 823 partition sorting data. Bull. Sociol. Methodol. 117, 93-105.

824 Huq, F.A., Chowdhury, I.N., Klassen, R.D., 2016. Social management capabilities of 825 multinational buying firms and their emerging market suppliers: An exploratory study of the 826 clothing industry. J. Oper. Manag. 46, 19-37.

827 ILO, I.L.O., 2002. Occupational Safety and Health in Bangladesh.

828 Islam, M.S., Tseng, M.-L., Karia, N., Lee, C.-H., 2018. Assessing green supply chain practices in 829 Bangladesh using fuzzy importance and performance approach. Resour. Conserv. Recycl. $830 \quad 131,134-145$.

831 Jayaram, J., Avittathur, B., 2015. Green supply chains: A perspective from an emerging 832 economy. Int. J. Prod. Econ. 164, 234-244.

833 Jones, P., Hillier, D., Comfort, D., 2011. Shopping for tomorrow: promoting sustainable 834 consumption within food stores. Br. Food J. 113, 935-948.

835 Kaufman, L., Rousseeuw, P.J., 2009. Finding groups in data: an introduction to cluster analysis. 836 John Wiley \& Sons. 
Kaur, J., Sidhu, R., Awasthi, A., Chauhan, S., Goyal, S., 2018. A DEMATEL based approach for investigating barriers in green supply chain management in Canadian manufacturing firms. Int. J. Prod. Res. 56, 312-332.

Khan, S.A.R., Dong, Q.L., Yu, Z., 2016. Research on the Measuring Performance of Green Supply Chain Management: In the Perspective of China. Int. J. Eng. Res. Africa 27, 167178.

Khan, S.A.R., Jian, C., Zhang, Y., Golpîra, H., Kumar, A., Sharif, A., 2019. Environmental, social and economic growth indicators spur logistics performance: From the perspective of South Asian Association for Regional Cooperation countries. J. Clean. Prod. 214, 10111023.

Khan, S.A.R., Qianli, D., 2017. Impact of green supply chain management practices on firms' performance: an empirical study from the perspective of Pakistan. Environ. Sci. Pollut. Res. $24,16829-16844$.

Khosla, N., 2009. The ready-made garments industry in Bangladesh: A means to reducing gender-based social exclusion of women? J. Int. Womens. Stud. 11, 289-303.

Koebel, C.T., McCoy, A.P., Sanderford, A.R., Franck, C.T., Keefe, M.J., 2015. Diffusion of green building technologies in new housing construction. Energy Build. 97, 175-185.

Kusaba, K., Moser, R., Rodrigues, A.M., 2011. Low-cost country sourcing competence: a conceptual framework and empirical analysis. J. Supply Chain Manag. 47, 73-93.

Lee, S.-Y., 2008. Drivers for the participation of small and medium-sized suppliers in green supply chain initiatives. Supply Chain Manag. An Int. J. 13, 185-198.

Lee, S.M., Kim, S.T., Choi, D., 2012. Green supply chain management and organizational performance",. Ind. Manag. Data Syst. 112, 1148-1180.

Lehtoranta, S., Nissinen, A., Mattila, T., Melanen, M., 2011. Industrial symbiosis and the policy instruments of sustainable consumption and production. J. Clean. Prod. 19, 1865-1875.

Lettenmeier, M., Göbel, C., Liedtke, C., Rohn, H., Teitscheid, P., 2012. Material Footprint of a Sustainable Nutrition System in 2050 - Need for Dynamic Innovations in Production, 
Consumption and Politics. Proc. Syst. Dyn. Innov. Food Networks 2012.

865

866

867

868

869

870

871

872

873

874

875

876

877

878

879

880

881

882

883

884

885

886

887

888

889

890

Lieder, M., Rashid, A., 2016. Towards circular economy implementation: a comprehensive review in context of manufacturing industry. J. Clean. Prod. 115, 36-51.

Liu, S., Kasturiratne, D., Moizer, J., 2012. A hub-and-spoke model for multi-dimensional integration of green marketing and sustainable supply chain management. Ind. Mark. Manag. 41, 581-588.

Long, T.B., Blok, V., Coninx, I., 2016. Barriers to the adoption and diffusion of technological innovations for climate-smart agriculture in Europe: evidence from the Netherlands, France, Switzerland and Italy. J. Clean. Prod. 112, 9-21.

Longoni, A., Golini, R., Cagliano, R., 2014. The role of New Forms of Work Organization in developing sustainability strategies in operations. Int. J. Prod. Econ. 147, 147-160.

Lorek, S., Fuchs, D., 2013. Strong sustainable consumption governance - precondition for a degrowth path? J. Clean. Prod. 38, 36-43.

Lorek, S., Spangenberg, J.H., 2014. Sustainable consumption within a sustainable economy beyond green growth and green economies. J. Clean. Prod. 63, 33-44.

Luthra, S., Kumar, S., Kharb, R., Ansari, M.F., Shimmi, S.L., 2014. Adoption of smart grid technologies: An analysis of interactions among barriers. Renew. Sustain. Energy Rev. 33, $554-565$.

Luthra, S., Kumar, V., Kumar, S., Haleem, A., 2011. Barriers to implement green supply chain management in automobile industry using interpretive structural modeling technique: An Indian perspective. J. Ind. Eng. Manag. 4, 231-257.

Majumdar, A., Sinha, S.K., 2019. Analyzing the barriers of green textile supply chain management in Southeast Asia using interpretive structural modeling. Sustain. Prod. Consum. 17, 176-187.

Mani, V., Gunasekaran, A., Delgado, C., 2018. Enhancing supply chain performance through supplier social sustainability: An emerging economy perspective. Int. J. Prod. Econ. 195, 259-272. 
Mathiyazhagan, K., Govindan, K., NoorulHaq, A., Geng, Y., 2013. An ISM approach for the barrier analysis in implementing green supply chain management. J. Clean. Prod. 47, 283297.

Moktadir, M.A., Rahman, T., Rahman, M.H., Ali, S.M., Paul, S.K., 2018. Drivers to sustainable

Mudgal, R.K., Shankar, R., Talib, P., Raj, T., 2010. Modelling the barriers of green supply chain manufacturing practices and circular economy: A perspective of leather industries in

Muduli, K., Barve, A., 2011. Role of green issues of mining supply chain on sustainable development. Int. J. Innov. Manag. Technol. 2, 484-489.

Muduli, K., Govindan, K., Barve, A., Kannan, D., Geng, Y., 2013. Role of behavioural factors in green supply chain management implementation in Indian mining industries. Resour. Conserv. Recycl. 76, 50-60.

Nayak, R., Akbari, M., Far, S.M., 2019. Recent sustainable trends in Vietnam's fashion supply chain. J. Clean. Prod. 225, 291-303.

Nazzal, D., Batarseh, O., Patzner, J., Martin, D.R., 2013. Product servicing for lifespan extension and sustainable consumption: An optimization approach. Int. J. Prod. Econ. 142, 105-114.

Nulty, D.D., 2008. The adequacy of response rates to online and paper surveys : what can be done? Assess. Eval. High. Educ. ISSN 33, 301-314.

O’Brien, K.J., Li, L., 1999. Selective policy implementation in rural China. Comp. Polit. 167186.

Oliveira, U.R. de, Espindola, L.S., Silva, I.R. da, Silva, I.N. da, Rocha, H.M., 2018. A systematic literature review on green supply chain management: research implications and future perspectives. J. Clean. Prod. 187, 537-561.

Pandit, D., Joshi, M.P., Sahay, A., Gupta, R.K., 2017. Disruptive innovation and dynamic capabilities in emerging economies: Evidence from the Indian automotive sector. Technol. Forecast. Soc. Change $0-1$. 
918 Parent, J., Cucuzzella, C., Revéret, J.-P., 2013. Revisiting the role of LCA and SLCA in the 919 transition towards sustainable production and consumption. Int. J. Life Cycle Assess. 18, $920 \quad 1642-1652$.

921 Prieto-Sandoval, V., Jaca, C., Ormazabal, M., 2018. Towards a consensus on the circular 922 economy. J. Clean. Prod. 179, 605-615.

923 Rakib, M.I., Saidur, R., Mohamad, E.N., Afifi, A.M., 2017. Waste-heat utilization - The 924 sustainable technologies to minimize energy consumption in Bangladesh textile sector. J. $925 \quad$ Clean. Prod. 142, 1867-1876.

926 Rao, P., Holt, D., 2005. Do green supply chains lead to competitiveness and economic 927 performance? Int. J. Oper. Prod. Manag. 25, 898-916.

928 Roos, S., 2015a. Towards Sustainable Use of Chemicals in the Textile Industry: How life cycle 929 assessment can contribute.

930 Roos, S., 2015b. Towards Sustainable Use of Chemicals in the Textile Industry: How life cycle $931 \quad$ assessment can contribute.

932 Rousseeuw, P.J., 1987. Silhouettes: A graphical aid to the interpretation and validation of cluster 933 analysis. J. Comput. Appl. Math. 20, 53-65.

934 Routroy, S., Shankar, A., 2014. A study of apparel supply chain risks. IUP J. Supply Chain 935 Manag. XI, 52-69.

936 Sarkis, J., 2003. A strategic decision framework for green supply chain management. J. Clean. 937 Prod. 11, 397-409.

938 Sheu, J., Chen, Y.J., 2012. Impact of government financial intervention on competition among 939 green supply chains. Int. J. Prod. Econ. 138, 201-213.

940 Smol, M., Kulczycka, J., Henclik, A., Gorazda, K., Wzorek, Z., 2015. The possible use of 941 sewage sludge ash (SSA) in the construction industry as a way towards a circular economy. 942 J. Clean. Prod. 95, 45-54.

943 Tanner, C., Kast, S.W., 2003. Promoting Sustainable Consumption: Determinants of Green 944 Purchases by Swiss Consumers. Psychol. Mark. 20, 883-902. 
945

946

947

948

949

950

951

952

953

954

955

956

957

958

959

960

961

962

963

964

965

966

967

968

969

Tseng, M.-L., Chiu, (Anthony) Shun Fung, Tan, R.R., Siriban-Manalang, A.B., 2013. Sustainable consumption and production for Asia: sustainability through green design and practice. J. Clean. Prod. 40, 1-5.

Tukker, A., 2015. Product services for a resource-efficient and circular economy--a review. J. Clean. Prod. 97, 76-91.

Urban, B., Naidoo, R., 2012. Business sustainability: empirical evidence on operational skills in SMEs in South Africa. J. Small Bus. Enterp. Dev. 19, 146-163.

Wadud, Z., Huda, F.Y., 2017. Fire Safety in the Readymade Garment Sector in Bangladesh: Structural Inadequacy Versus Management Deficiency. Fire Technol. 53, 793-814.

Whiteman, G., Walker, B., Perego, P., 2013. Planetary Boundaries: Ecological Foundations for Corporate Sustainability. J. Manag. Stud. 50, 307-336.

Wilson, D.C., 2007. Development drivers for waste management. Waste Manag. Res. 25, 198 207.

Zhang, X., Shen, L., Tam, V.W.Y., Lee, W.W.Y., 2012. Barriers to implement extensive green roof systems: A Hong Kong study. Renew. Sustain. Energy Rev. 16, 314-319.

Zhu, Q., Feng, Y., Choi, S.-B., 2017. The role of customer relational governance in environmental and economic performance improvement through green supply chain management. J. Clean. Prod. 155, 46-53.

Zhu, Q., Geng, Y., 2013. Drivers and barriers of extended supply chain practices for energy saving and emission reduction among Chinese manufacturers. J. Clean. Prod. 40, 6-12.

Zhu, Q., Sarkis, J., Lai, K., 2008. Confirmation of a measurement model for green supply chain management practices implementation. Int. J. Prod. Econ. 111, 261-273.

Zsidisin, G.A., Siferd, S.P., 2001. Environmental purchasing: A framework for theory development. Eur. J. Purch. Supply Manag. 7, 61-73.

(1)

